\title{
Absorption Levels and Morphological Features of Fetal Organs in Wistar Rats Treated with Lead Acetate
}

\author{
Niveles de Absorción y Características Morfológicas de los Órganos Fetales \\ en Ratas Wistar Tratadas con Acetato de Plomo \\ "Kátia Michelle dos Anjos Bomfim; *'Carlos Alexandre Borges Garcia; ***Francisco Prado Reis; **** José Arnaldo Vasconcelos \\ Palmeira; ${ }^{* * * *}$ Ricardo Scher; ${ }^{* * * * *}$ Waldecy de Lucca Júnior; ${ }^{* * * * *}$ José Adeval Aragão; ${ }^{*}$ Francis Lima Vasconcelos; \\ ${ }^{* * * * * *}$ Ricardo Luiz Cavalcanti Albuquerque Júnior; ${ }^{* * * * * *}$ Vera Lúcia Corrêa Feitosa
}

BOMFIM, K. M. A.; GARCIA, C. A. B.; REIS, F. P.; PALMEIRA, J. A. V.; SCHER, R.; DE LUCCA JÚNIOR, W.; ARAGÃO, J. A.; VASCONCELOS, F. L.; ALBUQUERQUE JÚNIOR, R. L. C. \& FEITOSA, V. L. C. Absorption levels and morphological features of fetal organs in wistar rats treated with lead acetate. Int. J. Morphol., 30(1):119-124, 2012.

SUMMARY: Lead is one of the heavy metals most used in industry. Poisoning due to long-term lead exposure is known as saturnism, and is an occupational illness that has been known for many years. Lead is highly toxic and can compromise the structural and functional patterns of organs and systems. The aim of this study was to examine the lungs and kidneys of fetuses from female Wistar rats exposed to lead acetate. In this study, the lungs and kidneys of 20 fetuses from female rats that had previously been treated with lead acetate were dissected, fixed, embedded in paraffin and stained with hematoxylin and eosin. Macroscopic changes to the shape, color and consistency of organs from fetuses treated with this heavy metal were observed, in comparison with organs from control fetuses. Microscopic lesions characterized by vascular sclerosis, cell atrophy or hyperplasia, progressive interstitial fibrosis, inclusion bodies containing lead acetate and glomerular sclerosis were found in the kidneys. The lesions found in the lungs consisted of destructuring of the parenchyma, impregnation with lead acetate, formation of fibrosis, extravasation of vascular fluids, reduction of the alveolar spaces and formation of alveolar edema. These changes were correlated with the level of lead acetate absorption, as determined using atomic spectrophotometry.

KEY WORDS: Lead acetate; Fetuses; Lung; Kidney.

\section{INTRODUCTION}

Since ancient times, lead has been one of the heavy metals most used by man for manufacturing utensils, arms and ornaments. There is evidence that it was already in use in Asia Minor in 4,000 BC (Nakamura, 2002). However, it only came into large-scale use from the eighteenth century onwards, when it started to be incorporated into emerging industrial processes (Audesirk, 1985). Its diversity of uses is attributed to its physical characteristics, such as: low melting point, ductility, and facility for forming metal alloys, malleability and resistance to corrosion. Despite the implementation of industrial hygiene measures, lead has been responsible for high incidence of poisoning among Brazilian workers (Smith et al., 1996).
Unlike other metals like iron, zinc, cobalt and copper, lead does not form part of the biological metabolism. Its absorption by the organism produces poisoning that is known as saturnism. This is a type of occupational illness, and it was first described in modern times by Tanquerel in 1839, based on 1200 cases (Nakamura). Initially, lead poisoning presents subclinically, but it tends to worsen through compromising different organs and systems, such as the kidneys, liver, central nervous system (CNS), peripheral nervous system (PNS) and the neuromuscular, hematopoietic, endocrine, reproductive and cardiovascular systems (Smith et al.; De Capitani, 2009). Rojas et al. (2003) reported that although lead exposure is declining in

\footnotetext{
Undergraduate medical student, Federal University of Sergipe, Aracaju, Sergipe, Brazil.

** Adjunct Professor, Department of Analytical Chemistry, Federal University of Sergipe, Aracaju, Sergipe, Brazil.

*** Titular Professor of the School of Medicine, Tiradentes University, Aracaju, Sergipe, Brazil.

***** Adjunct Professor, Department of Morphology, Federal University of Sergipe, Aracaju, Sergipe, Brazil.

******Research and Technology Institute/UNIT, Aracaju, Sergipe, Brazil.

${ }^{* * * * * *}$ Associate Professor, Department of Morphology, Federal University of Sergipe, Aracaju, Sergipe, Brazil.
} 
BOMFIM, K. M. A.; GARCIA, C. A. B.; REIS, F. P.; PALMEIRA, J. A. V.; SCHER, R.; DE LUCCA JÚNIOR, W.; ARAGÃO, J. A.; VASCONCELOS, F. L.; ALBUQUERQUE JÚNIOR, R. L. C. \& FEITOSA, V. L. C. Absorption levels and morphological features of fetal organs in wistar rats treated with lead acetate. Int. J. Morphol., 30(1):119-124, 2012.

developing countries, chronic contamination due to low-level exposure continues to be a significant problem for children's health.

Studies on the toxic action of lead on living organisms have been conducted for a long time. However, the findings still seem to be insufficient to explain what the mechanisms of action that originate these toxic effects are and how they function. Hence, research on the effects of lead on living organisms continue to be necessary in order to assist in understanding and consequently, preventing these effects (Moreira \& Moreira, 2004).

With the aim of contributing towards knowledge of the action of lead on living organisms, the present study had the objective of analyzing the structure and quantifying the absorption of lead in the lungs and kidneys of fetuses from female Wistar rats that were treated with different concentrations of lead acetate during pregnancy.

\section{MATERIAL AND METHOD}

Macroscopic analysis. Twenty full-term fetuses from female Wistar rats were used for this study. They were divided into four groups of five fetuses each, corresponding to different concentrations of lead acetate with which the rats were treated during pregnancy, for a mean period of 30 days. The concentrations used in three groups were 12.5, 25.0 and 50.0 $\mathrm{mg} / \mathrm{kg}$ of body weight, while the fourth group consisted of control animals that received distilled water instead of lead acetate (Freire et al., 2002). All the rats were kept in an ad libitum feeding regimen.

The fetuses were fixed in a $10 \%$ paraformaldehyde solution in Millonig's buffer (0.1 M phosphate at pH 7.4). After fixing, the lungs and kidneys of each fetus were dissected and analyzed macroscopically. Photographic documentation was produced, through images captured by a Sony Cybershot DSC-W80 7.1 digital camera.

Microscopic analysis. For the microscopic analysis, the kidneys and lungs were dehydrated in an increasing series of alcohol (70, 80, 95 and 100\%), diaphonized in xylol and embedded in paraffin blocks. The blocks were then sliced into histological sections of $6 \mathrm{~mm}$ in thickness. These were stained using Harris hematoxylin, as described by Behmer et al. (1976). The microscopic analyses were documented and the best fields were photographed using an Olympus C7070 Wide 2004 digital camera.

Lead acetate assays. The dissected samples from the lungs and kidneys of all the fetuses, which had been stored in a freezer at $-22^{\circ} \mathrm{C}$, were allowed to defrost at room temperature. Following this, the samples were placed on watch glasses that were numbered with identification codes corresponding to information on the respective samples that had been entered in a registration book. The moist weight of the samples used was then ascertained. Next, the total unfractioned masses of the samples were transferred to coded porcelain capsules and placed in a heated chamber with circulating renewed air at $60^{\circ} \mathrm{C}$ for a 24-hours period, in order to dehydrate the samples (Rayment \& Barry, 2000).

After 24 hours in the heated chamber, the samples were removed and fractioned with the aid of porcelain pestle and mortar, so that the mass used in the digestion could be better removed afterwards (around $500 \mathrm{mg}$ ). The material was packed in numbered plastic bags. Each sample was weighed in polytetrafluoroethylene (PTFE) reactor vessels. After this step, pumps were connected to the reactor domes to introduce $10 \mathrm{ml}$ of $65 \%$ nitric acid. The reactor vessels were then sealed and placed in the digester block for around two hours. After this, the pumps were removed from the digester block and the reactor domes were cooled. The resultant solution was transferred to a volumetric flask and ultra-pure water was added to make up the volume to $50 \mathrm{ml}$. The lead concentration was measured in an atomic absorption spectrophotometer with deuterium background corrector and the equivalence in terms of lead acetate concentration absorbed in the organs was determined (Rayment \& Barry).

Statistical analysis. The results from the experiments were expressed as means \pm standard error of the mean and were subjected to the parametric Student's t test after verifying that the data presented normal distribution. The GraphPad Prism ${ }^{\circledR}$ computer software (GraphPad Software, Inc., USA) was used for performing the analyses.

The present study was approved by the institution's ethics committee for animal research, under protocol number 24/2009, of April 16, 2009.

\section{RESULTS}

Macroscopic changes in relation to the control animals (Fig. 1a) were observed in all the lungs of fetuses from the female rats that were treated with lead acetate, at all the concentrations used. These changes occurred in relation to the shape, color and consistency of the lungs (Fig. 1b, c, d and e). Figure 1c shows the lead-impregnated pulmonary bronchial tree of a fetus that received lead acetate at the concentration of $12.5 \mathrm{mg} / \mathrm{kg}$ of body weight. On the 

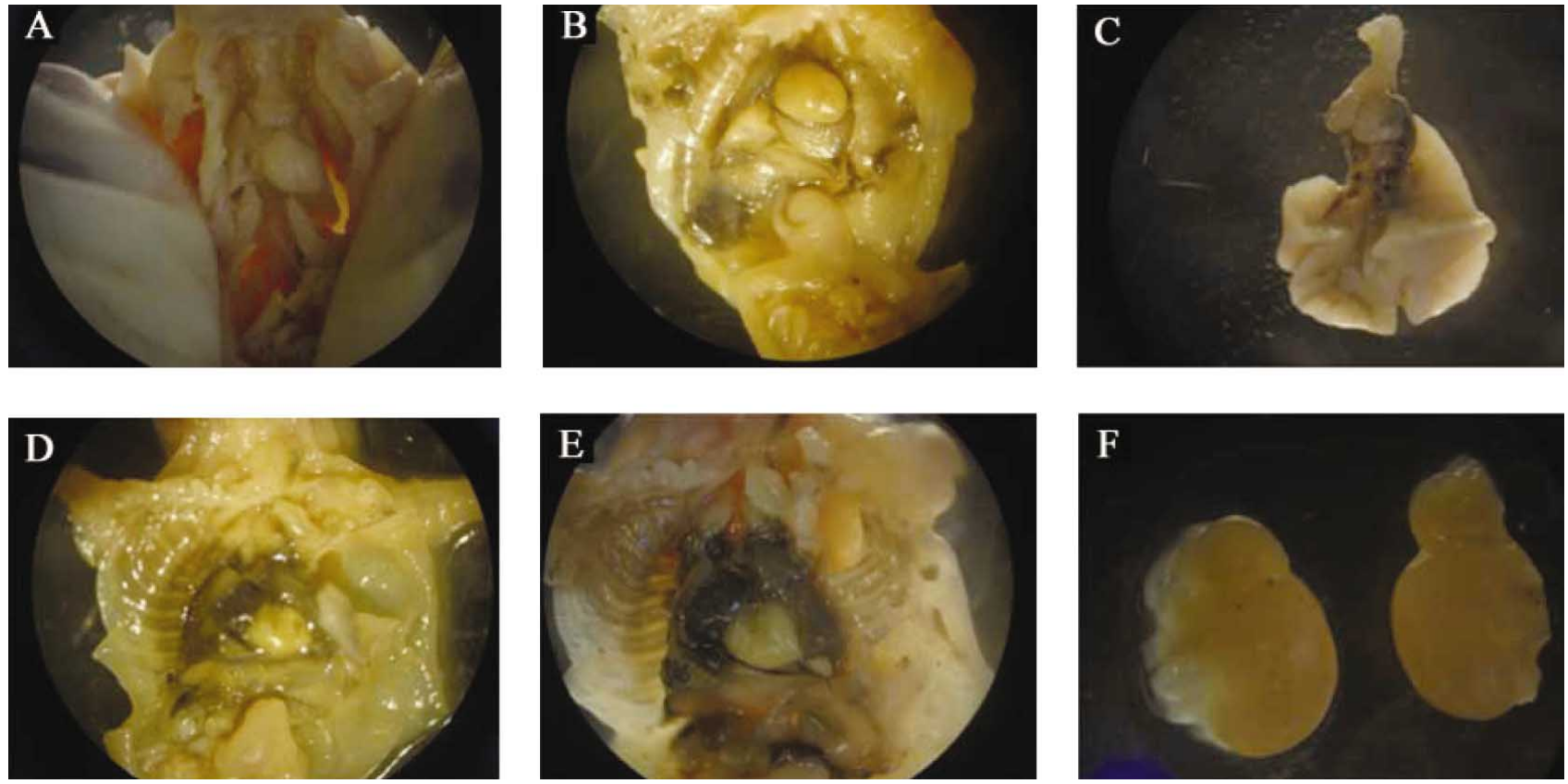

Fig. 1. Macroscopic analyses on the lungs and kidneys: (a) lung from control animal; (b) and (c) lungs treated with lead acetate at concentrations of $12.5 \mathrm{mg} / \mathrm{kg}$, (d) $25.5 \mathrm{mg} / \mathrm{kg}$ and (e) $50 \mathrm{mg} / \mathrm{kg}$; (f) kidney from animal treated with lead acetate at a concentration of $50.0 \mathrm{mg} / \mathrm{kg}$. Note the shape, color and consistency of the structures of the lungs and kidneys of the animals treated with lead acetate at the different concentrations. 10X.

other hand, macroscopic changes were only observed in the kidneys with the use of lead acetate at the concentration of $50.0 \mathrm{mg} / \mathrm{kg}$ of body weight (Fig. 1f).

At microscopic level, in comparison with the control animals (Fig. 2a), destructuring of the parenchyma was observed in the lungs of the fetuses from the female rats that received lead acetate solution, with formation of fibrosis (Fig. $2 \mathrm{~b}$ ), presence of acetate impregnation in the parenchyma and extravasation of vascular fluids in the fetuses treated with concentrations of $12.5 \mathrm{mg} / \mathrm{kg}$ and $25.0 \mathrm{mg} / \mathrm{kg}$ of body weight (Fig. 2c, $d$ and e). In the fetuses from the female rats that received treatment with a lead acetate concentration of $50.0 \mathrm{mg} / \mathrm{kg}$ of body weight, similar changes were observed but at a greater degree of intensity, diminished alveolar spaces and presence of alveolar edema (Figs. $2 \mathrm{f}$ and g).

In the kidneys, the use of lead acetate at concentrations of $12.5 \mathrm{mg} / \mathrm{kg}$ and $25.0 \mathrm{mg} / \mathrm{kg}$ of body weight produced disordering of the renal structure, especially the glomerular complex, and impregnation of lead acetate granules in perirenal structures (Figs. $2 \mathrm{~h}, \mathrm{i}$ and j), in comparison with the control animals (Fig. 2h). At a concentration of $50.0 \mathrm{mg} / \mathrm{kg}$ of body weight, the appearance of the microscopic renal changes was compatible with irreversible damage, characterized by the presence of sclerosis, glomerular atrophy and progressive interstitial fibrosis. Inclusion bodies containing lead acetate were few in number or absent (Figs. 2: 1 and m), like those found in the fetuses from female rats that were treated with acetate at a concentration of $25.0 \mathrm{mg} / \mathrm{kg}$ of body weight.

The rate of lead acetate absorption determined through atomic absorption spectrophotometry was seen to increase because of greater exposure of the fetuses to the different concentrations of lead acetate. Fig. 3 presents the lead acetate absorption levels for the kidneys and lungs, in relation to the concentrations of this heavy metal that were used. These findings reveal that the absorption of lead in the kidneys was significantly greater than in the lungs, with $p<$ 0.0001 for the parametric Student's t test.

\section{DISCUSSION}

Macroscopic changes were constantly found in the kidneys and lungs of the fetuses from the female rats treated with lead acetate. Stewart (1999) reported that the mean time for which lead remains in soft tissues is approximately 40 days. In the experiment of the present study, our supposition is that this length of time was sufficient for the lead to have 

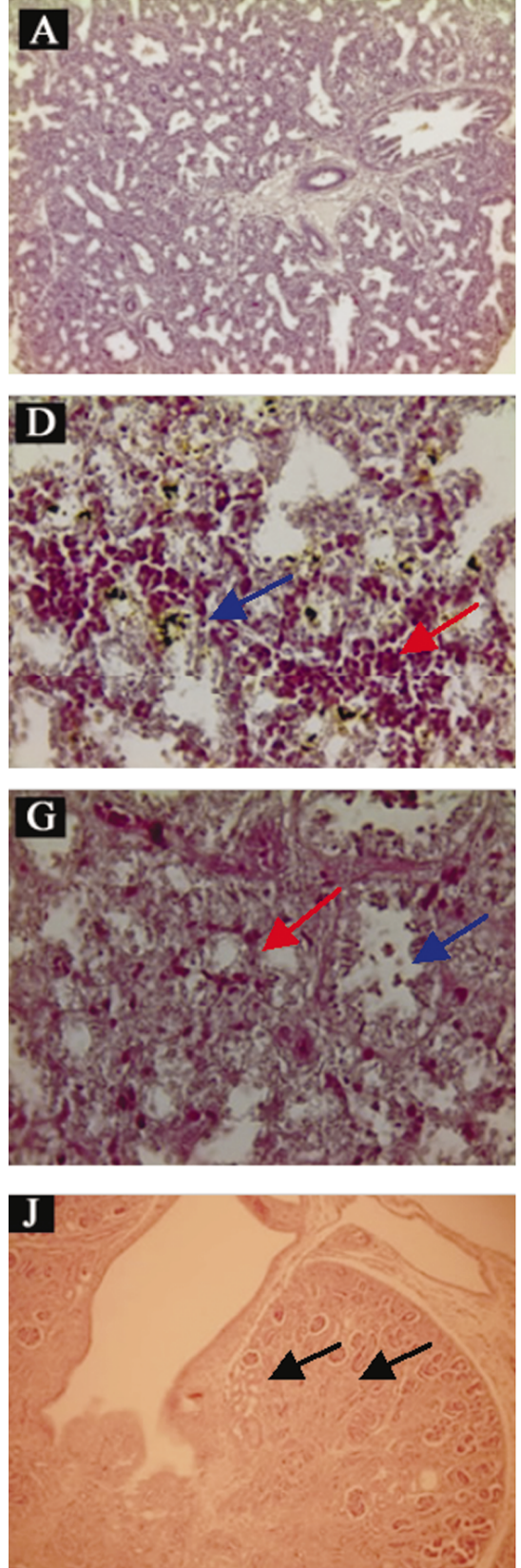
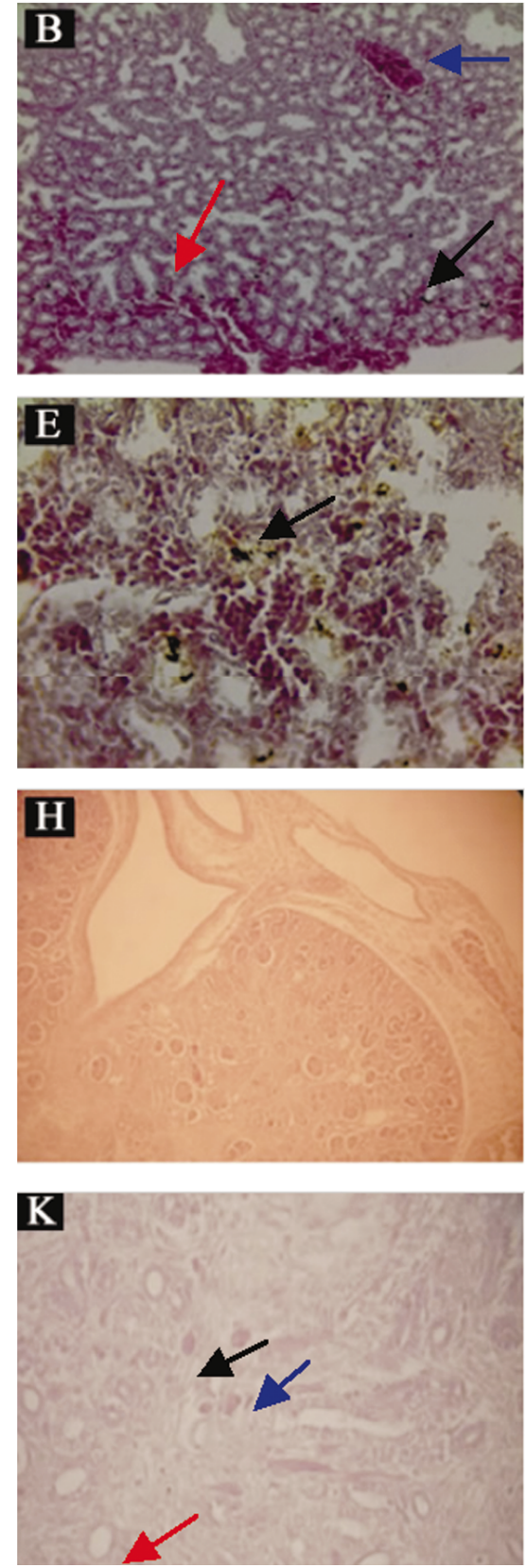

Fig. 2. Microscopic analyses: A. lung from control animal, 100X; B and C. Animals treated at a concentration of $12.5 \mathrm{mg} /$ $\mathrm{kg}$, presenting lead impregnation (black arrow), extravasation of vascular fluids (blue arrow) and destructuring of the pulmonary parenchyma (red arrow), 100X; D. (100X) and E. (400X), lung treated with $25.0 \mathrm{mg} / \mathrm{kg}$, with findings of lead impregnation (black arrow) and extravasation of fluids to extravascular areas (red arrow); F. (100X), with disordered pulmonary parenchyma (red arrow) and pulmonary edema (blue arrow); G. (400X), lung treated at a concentration of 50.0 $\mathrm{mg} / \mathrm{kg}$, presenting generally disordered pulmonary parenchyma (red arrow), accompanied by pulmonary edema (blue arrow); H. (100X), kidney from control animal; I (100X), animal treated with $12.5 \mathrm{mg} / \mathrm{kg}$ of lead acetate. Note lead impregnation (blue arrow) and structural changes to the glomerulus (black arrow); J. (100X), kidney from animal treated at a concentration of $25.0 \mathrm{mg} / \mathrm{kg}$. Lead impregnation can be seen (black arrow); L. (100X) and M. (400X), animals treated at a concentration of $50.0 \mathrm{mg} / \mathrm{kg}$, presenting glomerular atrophy (red arrow), degeneration of glomerulus (blue arrow) and normal glomeruli (black arrow). 
BOMFIM, K. M. A.; GARCIA, C. A. B.; REIS, F. P.; PALMEIRA, J. A. V.; SCHER, R.; DE LUCCA JÚNIOR, W.; ARAGÃO, J. A.; VASCONCELOS, F. L.; ALBUQUERQUE JÚNIOR, R. L. C. \& FEITOSA, V. L. C. Absorption levels and morphological features of fetal organs in wistar rats treated with lead acetate. Int. J. Morphol., 30(I):119-124, 2012.

\section{Lead absorption}

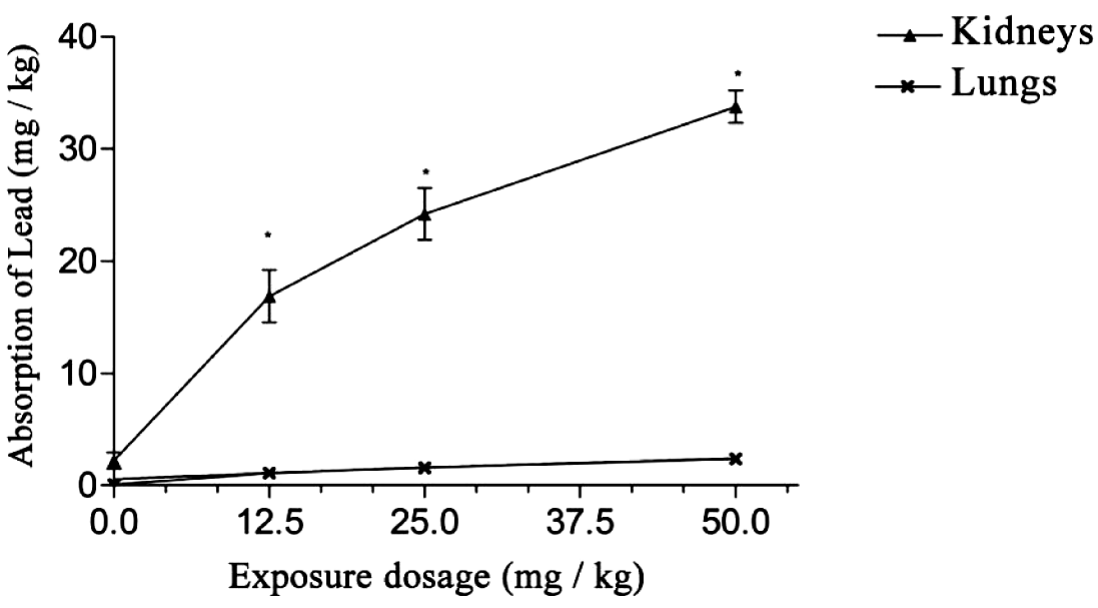

Fig. 3. Lead absorption level versus exposure to lead acetate, in the kidneys and lungs treated with led acetate at concentrations of $12.5,25.0$ and $50 \mathrm{mg} / \mathrm{kg}$ in fetuses from female Wistar rats. *, p 0.0001 versus same exposure dose in the lung. containing lead acetate and glomerular sclerosis, were similar to the findings reported by Mortada et al. and Moreira \& Moreira. However, differing from those authors, we found microscopic lesions in the kidneys at all concentrations of lead acetate use, and the lesions became worse in direct relation to the acetate concentration. However, macroscopic lesions in the kidneys were only evident at an acetate concentration of $50 \mathrm{mg} / \mathrm{kg}$ of body weight. We emphasize that glomerular atrophy lesions did not have a homogenous appearance within the same crosssectional level. crossed the placental barrier at high enough concentrations to produce the observed macro and microscopic changes in these organs.

The kidneys excrete lead in two ways: glomerular filtration and transtubular secretion. However, Henretig (2002) reported that 65 to $70 \%$ of the lead absorbed would be eliminated through these routes and the remainder through the biliary route. According to Saryan \& Zenz (1994), the toxic effects of lead on the kidneys occur in the presence of relatively high levels of lead and can be mainly divided into reversible renal tubular dysfunction and irreversible interstitial nephropathy.

This occurred in kidneys in which macroscopic changes were only detected at a concentration of $50 \mathrm{mg} / \mathrm{kg}$ of body weight. Alessio \& Foà (1983) and Mortada et al. (2001) highlighted that the kidneys, along with the nervous system and the bone marrow, are critical organs with regard to sensitivity to lead poisoning. They also highlighted that chronic exposure of the kidneys can be characterized by the presence of vascular sclerosis, atrophy or hyperplasia of tubular cells, progressive interstitial fibrosis, absence or rare inclusion bodies and glomerular sclerosis.

In the present study, the microscopic lesions found in the kidneys, such as vascular sclerosis, cell atrophy or hyperplasia, progressive interstitial fibrosis, inclusion bodies
Gomes (2002) correlated cardiopulmonary death with the toxic action of lead. Lead absorption and poisoning through the airway has been much discussed. However, we did not find any studies analyzing the effect of lead absorption across the placenta, in organs such as the kidneys and lungs. The microscopic lesions found at lung level seemed to lead gradually towards a physiopathological condition in which the gas exchanges needed to maintain life became impossible.

The absorption rates determined by atomic absorption spectrophotometry were directly correlated with higher fetal exposure to lead acetate concentrations and with the type and degree of structural changes to each organ under examination. The kidneys had higher lead absorption rates than the rates seen in the lungs. This appears to be fully compatible with the physiological functions. Morgan \& Rhea (1991) highlighted that the kidneys, along with the nervous system and the bone marrow, are critical organs with regard to sensitivity to lead poisoning. In light of the results obtained through macro and microscopic analyses, we can conclude that exposure to lead acetate during pregnancy led to accumulation of this heavy metal in vital organs such as the lungs and kidneys of fetuses from female Wistar rats. We hope that these results may provide a contribution towards understanding the lesions that lead can produce, starting from fetal age. 
BOMFIM, K. M. A.; GARCIA, C. A. B.; REIS, F. P.; PALMEIRA, J. A. V.; SCHER, R.; DE LUCCA JÚNIOR, W.; ARAGÃO, J. A.; VASCONCELOS, F. L.; ALBUQUERQUE JÚNIOR, R. L. C. \& FEITOSA, V. L. C. Absorption levels and morphological features of fetal organs in wistar rats treated with lead acetate. Int. J. Morphol., 30(1):119-124, 2012.

BOMFIM, K. M. A.; GARCIA, C. A. B.; REIS, F. P.; PALMEIRA, J. A. V.; SCHER, R.; DE LUCCA JÚNIOR, W.; ARAGÃO, J. A.; VASCONCELOS, F. L.; ALBUQUERQUE JÚNIOR, R. L. C. \& FEITOSA, V. L. C. Niveles de absorción y características morfológicas de los órganos fetales en ratas Wistar tratadas con acetato de plomo. Int. J. Morphol., 30(1):119-124, 2012.

RESUMEN: El plomo es un metal pesado utilizado en la industria. El envenenamiento debido a la exposición prolongada por plomo es una enfermedad profesional conocida por muchos años. La toxicidad del plomo es muy expresiva y puede poner en peligro el modelo estructural y funcional de los órganos y sistemas. El objetivo de este estudio fue examinar los pulmones y riñones de fetos de ratas Wistar expuestos al acetato de plomo. En este estudio, 20 fetos de ratas Wistar previamente tratados con acetato de plomo durante la gestación, tuvieron sus órganos disecados, fijados, incluidos en parafina y teñidos con hematoxilina y eosina. Macroscópicamente, los órganos fetales tratados por este metal fueron comparados con los órganos de fetos controles en relación a forma, color y consistencia. Microscópicamente, se encontraron lesiones en el riñón que se caracterizaron por esclerosis vascular, atrofia o hiperplasia de células, fibrosis intersticial progresiva, presencia de cuerpos de inclusión que contenían acetato de plomo y esclerosis glomerular. En el pulmón se observó desorganización del parénquima impregnado con acetato de plomo, formación de fibrosis, líquido intersticial, reducción de los espacios alveolares y edema alveolar. Estos cambios se correlacionaron con el nivel de absorción de acetato de plomo, determinado por espectrometría atómica.

PALABRAS CLAVE: Acetato de plomo; Fetos; Pulmón; Riñon.

\section{REFERENCES}

Alessio, L. \& Foà, V. Lead. In: Alessio, L.; Berlin, A.; Roi, R. \& Boni, M. Human biological monitoring of indutrial chemicals se ies. Brussels, Luxembourg, Commission of The European Communities, 1983.

Audesirk, G. Effects of lead exposure on the physiology of neurons. Prog. Neurobiol., 24:199-231, 1985.

Behmer, O. A.; Tolosa, E. M. C. \& Freitas Neto, A. G. Manual de técnicas para microscopia normal e patológica. São Paulo, Edusp, 1976. pp.173-8.

De Capitani, E. M. Metabolismo do chumbo em crianças e adultos. Medicina, 42:268-76, 2009.

Freire, E. R.; Pantaleão, S. M. \& Scher, R. Avaliação do Efeito da Ingestão de Acetato de Chumbo Durante a Gestação de Ratas Wistar. Bol. Cent. Biol. Reprod. Juiz de Fora, 12:59-70, 2002.

Gomes, M. J. M. Ambiente e pulmão. J. Pneumol., 28:261-9, 2002.

Henretig, F. M. Lead. In: Goldfrank, L. R. (Ed.). Goldfrank's Toxicologic Emergencies. New York, McGraw-Hill, 2002. pp.1200-27.

Morgan, F. \& Rhea, H. Clinical and laboratory findings in small companion animals with lead poisoning. Am. Vet. Med. Assoc., 199:93-7, 1991.

Mortada, W. I.; Sobh, M. A.; El-Defrawy, M. M. \& Farahat, S. E. Study of lead exposure from automobile exhaust as a risk for nephrotoxicity among traffic policemen. Am. J. Nephrol., 21:274-9, 2001.

Moreira, F. R. \& Moreira, J. C. Os efeitos do chumbo sobre o organismo humano e seu significado para a saúde. Rev. Panam. Salud Pública, 15:119-29, 2004.
Nakamura, M. S. Intoxicação por chumbo. Rev. Oxidologia, 11:3742, 2002.

Rayment, G. E. \& Barry, G. A. Indicator tissues for heavy metal monitoring. Marine Poll. Bull., 41:353-8, 2000.

Rojas, M.; Espinosa, C. \& Seijas, D. Asociación entre plomo en sangre y parâmetros sociodemográficos en población infantil. Rev. Saúde Pública, 37:503-9, 2003.

Saryan, L. A. \& Zenz, C. Lead and its compounds. In: Zenz, O. C.; Dickerson, B. \& Horvath, E. P. (Eds.). Occupational medicine. 3rd ed. St. Louis, Mosby-Year Book, 1994. pp.506-41.

Smith, R. D.; Osterloh, J. D. \& Flegal, A. R. Use of endogenous, stable lead isotopes to determine release of lead from the skeleton. Environ. Health Perspect., 104:60-6, 1996.

Stewart, W. F. Lead acetate: Health effects, mechanisms of actions and research issues. Environ. Health Perspect., 107:593, 1999.

Correspondence to:

Francisco Prado Reis

Federal University of Sergipe

Aracaju, Sergipe

BRAZIL

Email: franciscopradoreis@gmail.com

Received: 13-04-2011

Accepted: 12-12-2011 